\title{
Evaluation and analysis criteria of the environmental risk factor of the anthropic perturbation in the infrastructure works
}

\author{
G. Gecchele \& G. Pizzo \\ Land, Environment and Geo-Engineering Department, \\ Turin Polytechnic, Italy
}

\begin{abstract}
The present study represents a methodological example of the knowledge of the territory through the identification of the qualitative parameters that give technical information of the territory characteristics, of the environmental effects and changes due to anthropic perturbation.

In this work some analysis and evaluation criteria of the environmental risk factors are presented, due to the infrastructure works, in order to supply the planning choices and to manage the execution phase, referring to great infrastructure works.

In particular, this work, relating to the meaning of impact and environmental quality established by the literature, wants to present a check list for the environmental analysis, which is applied as an example to a phase of an infrastructure work and which represents an important scheme to identify, to analyse and finally to evaluate the necessary information to reach the environmental safety.

Keywords: environmental analysis and evaluation, infrastructure works, environmental safety.
\end{abstract}

\section{Introduction}

The great civil infrastructure works need specific analyses aimed to identify, evaluate and manage the environmental impacts.

It is then necessary to establish which is the environmental state before the beginning of the works, in order to understand its possible evolution. 
The study of the relation between the anthropic activities and the environment [1] needs to take into account not only the physical, chemical and biologic components of the environment self, but also the social and economic dynamics of the community, the relations, the structure, the energetic balances [2], in order to understand the whole induced impact.

Every action which is done on the territory produces an alteration of the environmental parameters. Such alteration normally presents positive and negative aspects and has to be compared to the induced benefits and to the environmental and social costs.

The present study wants to study the negative environmental effects produced by the great and continuative infrastructure works; it will be taken into account the only environmental system, leaving to the specific disciplines the complementary analyses of the social and economic dynamics and the relevant costs and benefits.

The criticities of the environmental alterations have to be analyzed at first in the planning phase, by the application of the study models of the ecosystem response deriving to the anthropic pressure levels. The consequent decreasing of the environmental state quality will produce a decreasing of the environmental safety, which is the condition of absence of danger and of safeguard of the population and ecosystem integrity. Such decreasing will be related to the check and control procedures, put into act to manage the impacts.

\section{Environmental quality, environmental impact}

The environmental impact, according to the definition of Malcevschi [3] is the consequence of the action of a source that, after a more or less complex sequence of events, generates pressures on environmental targets, which could also be altered.

In order to limit the impact due to an intervention on the territory, it is necessary to study in the planning phase the possible modifications induced on the environment and on the existing anthropic activities.

The dimension and the importance of the impacts is related to the possible increasing of the risk on the safety and health of the exposed population [4], to the variation of availability of the existing resources and to the impossibility to reach the aims of safeguard and of environmental quality expressed by the local administration and by the scientific and cultural community. The sum of such factors implies a decreasing of the environmental safety.

These evaluations have to be integrated with the principles of sustainable development, put into act by the local authorities and aimed to the integration of all the interested social, politic, economic, administrative and legal subjects [5].

If the local authorities can put into act the criteria for a local sustainable development, the real problem is the interaction with the global system (national or international) [6] whose dynamics of sustainable development could be different or incompatible with the local decisions.

The infrastructural networks are a typical example of action that often shows the contradiction between the local and global development models that, 
although pursuing the same principles, however they don't collaborate on the dynamics of environmental and social economic development.

The great infrastructure works show how the natural system factors involve in particular the local system, without interacting, sometimes not at all, with the global system.

If it is not possible to understand what will be the destiny of the global ecosystem, it is possible and necessary to study the different scenarios of the evolution deriving from the different strategies and politics of safeguard in the local system.

The analysis of the ecologic systems and their interaction with the social and economic systems, have moreover permitted to put into act adequate programming and control instruments aimed to pursuit a sustainable development of the territory.

In the next paragraph are underlined the correlation between some of these instruments, with particular attention to the evaluation and control instruments.

\section{Correlation environmental state - environmental evaluation}

The instruments for the environmental evaluation are aimed to analyze the criticities deriving from the perturbation of one or more elements of the environmental sphere, of the health and of the territory.

In order to apply such instruments, it is at first necessary to analyze the level of perturbation of the environment due to a specific pressure and to correlate such perturbation to the existing environmental state. It is then necessary to introduce some definitions that represent the modification of the environmental state.

The "persistence" describes the state in which an environmental system does not modify its inner structure, due to external interferences.

The "resilience" indicates the capacity of a system to maintain its own structure, due to external interferences.

The "inertia" is the capacity of a system to maintain its own dynamicity.

The "collapse" is a fast modification of the system directed to a definitive destruction.

It is possible to represent the evolution of the environmental state, due to pressures generated by the realization of an intervention on the territory, with different cases.

1) In the case 1 , there is an event (construction of a work) on time $t_{0}$. The environment component passes from a condition of persistence to a condition of resilience. If the system can support the intensity of the pressure, then the environmental state, when the work is finished (time $t_{\mathrm{f}}$ ), could come back to same beginning level and stay in a condition of persistence. The environmental safety is safeguarded.

The environmental impact is represented by the colored area between the straight line without intervention and the curve after the intervention (case1). 


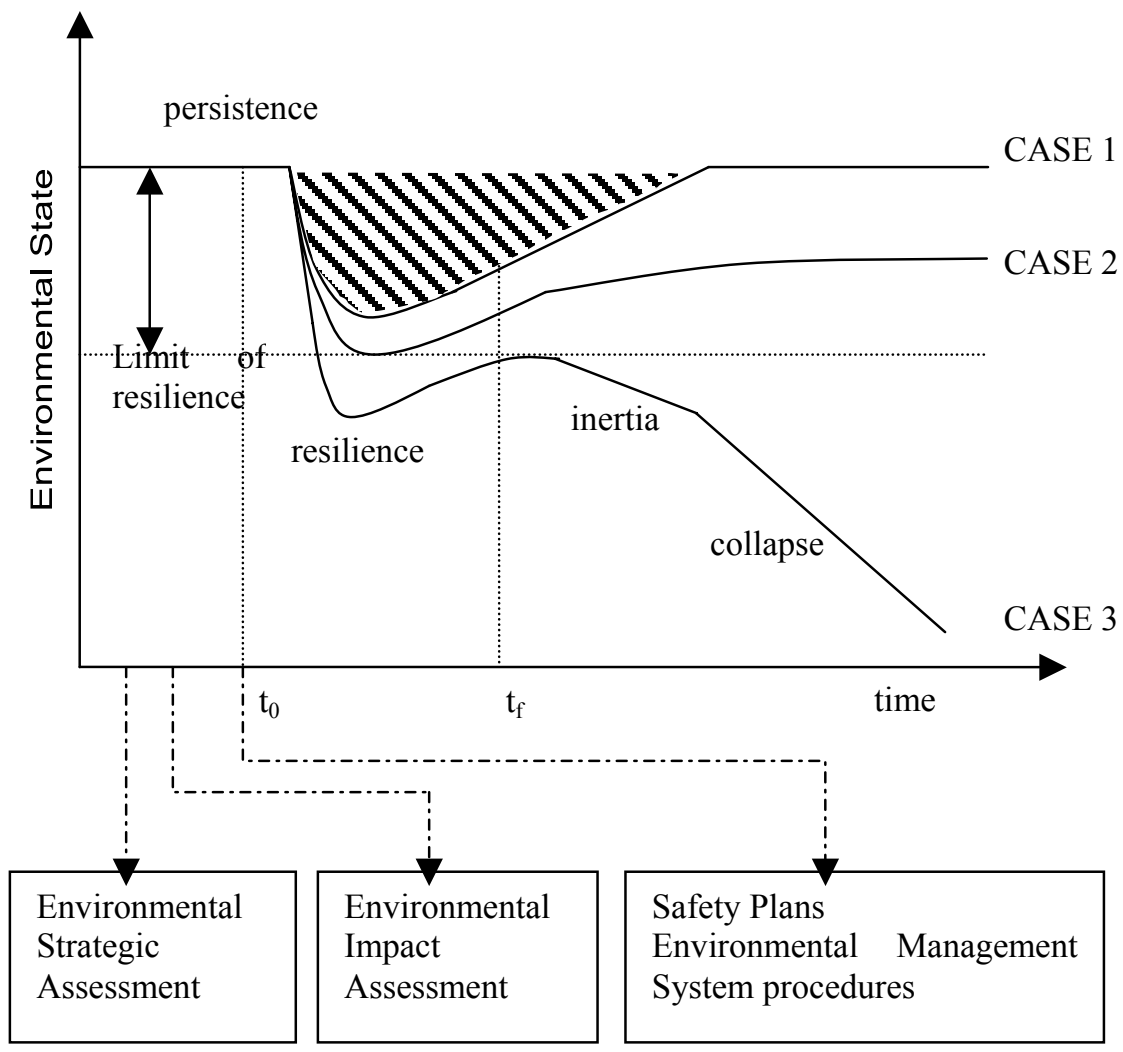

Figure 1: Effects of the impacts on the system.

2) If the pressure on the system is important (i.e. the great infrastructure works), after the phase of resilience, the environmental state can reach different levels of persistence, according to the entity of the impact, represented by the area between the straight line without the intervention and the curve after the intervention (case 2). In this case the system has been impacted, but it can come back to a condition of persistence.

3 ) If the system cannot support the pressure of an intervention, the resilience limit will be exceeded and when the work is finished, the environmental state will present a lower level respect to the beginning condition of persistence, and moreover it will decay (case 3). Such decay will reach the collapse in different times, depending on the inertia of the system.

Considering the complexity of the conflicts due to the interaction between the human activities and the environmental dynamics, the application field of the environmental evaluation is wide [7]. 
From a general to a particular application, the evaluation can interest plan and territorial programs (Strategic Environmental Assessment, Ecologic Incidence Assessment), preliminary and definitive projects (Environmental Impact Assessment, Ecologic Incidence Assessment, Safety Plans), existing plants or executive projects (Integrated Environmental Prevention, Operative Safety Plans, Environmental Management System).

It is possible to find a relation between such evaluation instruments and the effects of the impacts on the examined system. The Strategic Environmental Assessment, that represents a preventive instrument of global evaluation, is directly related to the beginning state of the system, since it studies the phase of programming, before the work is planned.

In this programming phase, the Environmental Impact Assessment studies the system after the Strategic Environmental Assessment, but before the perturbation state of the system, since it evaluates the project.

The results of the planning choices after an environmental impact evaluation should make the system maintain its own structure, safeguarding not only the compatibility, but also the sustainability. The Operative Safety Plans and the Environmental System Management (ISO 14000, EMAS) can be acted in the executive phase and are aimed to avoid the exceeding of the resilience limit.

For that situations on the limit of the environmental collapse, the operation of control and mitigation of the impacts are more complex, since the system lost its elasticity.

Such instruments should then be able to manage the impacts from the first phase of execution of the infrastructure works, in order to make the system maintain its inner elasticity.

\section{Criteria for the environmental analysis and evaluation}

The environmental evaluation of a project or the construction phase of an infrastructure work is not a rigid scheme, but it is an dynamic instrument that depends on the meaning of evaluation. In every case the evaluation is aimed to check the relation between the intervention and the safeguard of the environment, according to the principles of the environmental sustainability.

In order to make detailed evaluations of an area interested by a project, it is at first necessary to make a descriptive analysis of the characteristics of the project self. After a first descriptive analysis there should be a phase of qualitative evaluation and, when it is possible to get data from available sources or direct measurements, the evaluation can be quantitative. Such evaluation, through the use of adequate instruments, can give and estimation of the alterations due to the realization of the project.

The descriptive analysis can be done by check lists, yet used by the control authorities [8], which are a selected list of environmental factors, structured on the different target to be reached (description of the impact related to the project, knowledge of the possible alternatives of the project, indication of the environmental components with indicators). 
The present study wants to show a check list which is structured beginning from the description of the activities indicated by the project to the identification of the risk, in order to represent a reference guide for the environmental evaluation.

In tab. 1 there is an example of check list for the environmental analysis in the construction of streets, applied to a classical macro phase, expressed by the literature [9], of preparation, boundary and cleaning of the area interested by the infrastructure work.

The activities are divided into phases and subphases and are linked to the environmental aspects, which are defined by the EMAS as the elements of the activities that have an interaction with the environment [10]. For each environmental aspect the interested environmental component and the consequent risk for the environmental safety have been identified. The risk for the environmental safety is the possible modification of the environmental state, of safety and health of the population that can be represented by pollution, by consumption of raw material and energy, by an annoyance or an environmental disaster.

In the check list specific indicators have been also identified. Such indicators, which can be used in the following evaluation phase, represent and measure particular environmental impacts. Moreover this checklist links the impact to the interested phase of the activity (correlation source - effect).

The items in the check lists have to be identified according to the specific activity and territory which is studied and have to be separated in sub items in order to permit a complete evaluation of the environmental impacts.

In order to apply the indicators to the specific areas which have to be studied, they should be able to represent the measures of the environmental monitoring. It is important to take into account not only the possible damage conditions, but also the annoyance ones. The indicator should then represent the beginning environmental state and measure the variation of the examined parameter. The comparison with the existing situation permits to evaluate if the environmental condition is more or less critical (disturbance - annoyance - damage).

It is then necessary to get information on the environmental system concerning the area interested by a project. Such information, with the analysis of the environmental aspects of the project, make possible to identify and evaluate, through specific indicators, every impact of an infrastructure work.

If the beginning environmental state is good, the impact of an infrastructure work can not be critic, but its effect will be a decreasing of the environmental quality. Moreover if the beginning environmental state is not good, a little decrease of the environmental quality could generate the collapse of the system, that means a condition of damage. The indicators should then be related to the examined system in order to give important information for a correct environmental evaluation [11]. 
Table 1: $\quad$ Example of check list for the environmental evaluation.

\begin{tabular}{|c|c|c|c|c|}
\hline $\begin{array}{l}\text { Detail of the } \\
\text { operative } \\
\text { phases }\end{array}$ & $\begin{array}{l}\text { Environmental } \\
\text { aspects }\end{array}$ & $\begin{array}{l}\text { Environmental } \\
\text { components }\end{array}$ & $\begin{array}{c}\text { Identification } \\
\text { of the risk for } \\
\text { the } \\
\text { environmenta } \\
\text { I safety }\end{array}$ & $\begin{array}{c}\text { Indicators for } \\
\text { the } \\
\text { environmental } \\
\text { evaluation }\end{array}$ \\
\hline \multicolumn{5}{|c|}{ MACRO PHASE: PREPARATION, BOUNDARY AND CLEANING OF THE AREA } \\
\hline \multirow[t]{3}{*}{ Boundary } & \multirow[t]{2}{*}{$\begin{array}{l}\text { Modification of } \\
\text { the vehicular } \\
\text { traffic }\end{array}$} & $\begin{array}{l}\text { Antroposphere, } \\
\text { biosphere }\end{array}$ & $\begin{array}{l}\text { Local } \\
\text { acoustical } \\
\text { pollution }\end{array}$ & Sound level \\
\hline & & Atmosphere & $\begin{array}{l}\text { Local } \\
\text { emission }\end{array}$ & $\begin{array}{l}\text { Concentration of } \\
\text { combustion } \\
\text { products }\end{array}$ \\
\hline & $\begin{array}{l}\text { Installation of } \\
\text { boundary } \\
\text { structures }\end{array}$ & Antroposphere & $\begin{array}{l}\text { Visibile } \\
\text { impact }\end{array}$ & $\begin{array}{l}\text { Reduction of } \\
\text { visible cones }\end{array}$ \\
\hline $\begin{array}{l}\text { Installation } \\
\text { of mobile } \\
\text { and } \\
\text { stationary } \\
\text { equipment }\end{array}$ & - & - & - & - \\
\hline \multirow{6}{*}{$\begin{array}{l}\text { Elimination } \\
\text { of loam soil, } \\
\text { disafforestati } \\
\text { on, ground } \\
\text { leveling }\end{array}$} & \multirow[t]{2}{*}{$\begin{array}{l}\text { Elimination of } \\
\text { loam soil, } \\
\text { disafforestation }\end{array}$} & Lithosphere & $\begin{array}{l}\text { Increasing of } \\
\text { land } \\
\text { vulerability }\end{array}$ & $\begin{array}{l}\text { Concentration of } \\
\text { chemical } \\
\text { substances }\end{array}$ \\
\hline & & Hydrosphere & $\begin{array}{l}\text { Increasing of } \\
\text { land porosity }\end{array}$ & $\begin{array}{l}\text { Concentration of } \\
\text { chemical } \\
\text { substances }\end{array}$ \\
\hline & Ground leveling & Atmosphere & $\begin{array}{l}\text { Dust } \\
\text { production }\end{array}$ & $\begin{array}{l}\text { Concentration of } \\
\text { dust }\end{array}$ \\
\hline & $\begin{array}{l}\text { Mucking } \\
\text { removal }\end{array}$ & Lithosphere & $\begin{array}{l}\text { Waste } \\
\text { production }\end{array}$ & $\begin{array}{l}\text { Quantity of } \\
\text { waste }\end{array}$ \\
\hline & \multirow[t]{2}{*}{$\begin{array}{l}\text { Movement of } \\
\text { dumpers and } \\
\text { equipment }\end{array}$} & Atmosphere & $\begin{array}{l}\text { Release of } \\
\text { combustion } \\
\text { products }\end{array}$ & $\begin{array}{l}\text { Concentration of } \\
\text { combustion } \\
\text { products }\end{array}$ \\
\hline & & $\begin{array}{l}\text { Antroposphere, } \\
\text { biosphere }\end{array}$ & $\begin{array}{l}\text { Acoustical } \\
\text { pollution }\end{array}$ & Sound level \\
\hline $\begin{array}{l}\text { Conveyance } \\
\text { and } \\
\text { movement of } \\
\text { surface } \\
\text { waters }\end{array}$ & $\begin{array}{l}\text { Modification of } \\
\text { watercourse }\end{array}$ & $\begin{array}{l}\text { Antroposphere, } \\
\text { biosphere }\end{array}$ & $\begin{array}{l}\text { Reduction/incr } \\
\text { ement of flow } \\
\text { rate }\end{array}$ & $\begin{array}{l}\text { Variation of flow } \\
\text { rate }\end{array}$ \\
\hline
\end{tabular}




\section{Conclusions}

The meaning of environment as the sum of the physical, chemical and biologic conditions is reductive, a linear relation cannot take into account every interested part [12], nor represent the relations of an Ecologic, Social and Economic System. The best definition of environment is a whole of systems, with their inner dynamics, relations, structures and energetic balances.

It is important to choice adequate indicators to make a correct evaluation, in order to establish administrative and planning procedures aimed to face the environmental impacts, due to the realization of a project inside a territory.

Such indicators should find a correlation in the different level of schemes for the environmental evaluation, from the Environmental Strategic Assessment, to the Environmental Impact Assessment arriving to the Operative Safety Plans, in the case of the infrastructure works.

The final target is to pursuit a condition of environmental safety, safeguarding the health and integrity of the population and the ecosystem quality, operating then not only for the control of the pollution, but for the environmental, economic and social sustainable development.

The only compatibility is not enough to assure a development finalized to maintain a high ecosystem quality level. It is necessary then to be able to evaluate the capacity of a territory to support the impacts, in order to establish management procedures for the environmental safety.

To reach this target, the methodological instrument for the knowledge of the territory, which is necessary to get information on the effects and modification induced on the environment, should use the analysis and evaluation criteria of the environmental risk described in this study. The operative steps to get information for the environmental safety in the case of an infrastructure work, should be following:

- analysis of the documents. This phase is necessary to understand the legislation and the technical procedures which should be applied to an infrastructure work. It is then necessary to identify and analyze the compulsory and voluntary norms for the environmental, safety and health control and safeguard. Moreover it is necessary to analyze the documents belonging to the local administration and to the company concerning the risk for the environmental safety.

- environmental analysis. The pollution sources are identified and related to their effects. The environmental state is evaluated by the use of appropriate indicators.

- environmental evaluation. This phase wants to underline the environmental criticities of the infrastructure work, by evaluating the environmental impacts, through the studying of an evaluation criteria.

The application of such operative scheme to the infrastructure works will permit to calibrate the analysis methodology indicated by the present study, and will be object of thorough examination. 


\section{References}

[1] Taylor, William M., The vital landscape: nature and the built environment in nineteenth-century Britain, William M. Taylor. Aldershot; Burlington : Ashgate, 2004, 252 pp.

[2] Afgan, Naim H. Sustainable development of energy, water and environment systems: proceedings of the conference on sustainable development of energy, water and environment systems, 2-7 June 2002, Dubrovnik, Croatia, Naim H. Afgan, Zeljko Bogdan, Neven Duic'. Lisse : Balkema, 2004, 367 pp.

[3] Malcevschi S., Qualità ed impatto ambientale, Etaslibri, Milano, 1991, $355 \mathrm{pp}$.

[4] Gerrard, Simon, Environmental risk planning and management, Simon Gerrard, R. Kerry Turner and Ian J. Bateman. - Cheltenham : Elgar, 2001, $615 \mathrm{pp}$.

[5] Clerico M., Pizzo G., Environmental issues for sustainability development in underground works, IABSE Symposium 'Towards a better built environment - innovation, sustainability, information technology', Melbourne 11-13 September 2002; p. 106,107; CD p.1-8

[6] Naveh Z., Lieberman A., Landscape Ecology, Springer-Verlag, New York, 1994

[7] Ravetz, Joe, City - Region 2020 : Integrated planning for a sustainable environment, Joe Ravetz. - London : Earthscan, 2000, 307 pp.

[8] Arpa Piemonte, Sostenibilità ambientale dello sviluppo, Arpa Piemonte, Torino 2002, 367 pp.

[9] Comitato Paritetico Territoriale Per La Prevenzione Infortuni, L'igiene E L'ambiente Di Lavoro Di Torino E Provincia, Conoscere per prevenire n.12, Valutazione dei rischi nel settore delle costruzioni, vol.1, CPT, Torino, 2005, $802 \mathrm{pp}$.

[10] Regulation (EC) No 761/2001 of the European parliament and of the council of 19 March 2001 allowing voluntary participation by organisations in a Community eco-management and audit scheme (EMAS), Official Journal of the European Communities L 114 Vol.44, pag. 1 on 24 April 2001

[11] Australian And New Zeland Environment And Conservation Council 1996. Canberra : Dept. of the Environment and Heritage, 1996

[12] Bottero M., Mondini G., Valle M., Verso una pianificazione ambientale compatibile: $i$ piani territoriali di coordinamento, GEAM rivista della Associazione Georisorse e Ambiente, No. 104, December 2001, pp $265-$ 269. 